CRYSTALLOGRAPHIC COMMUNICATIONS

ISSN 2056-9890

Received 17 October 2019

Accepted 13 November 2019

Edited by M. Weil, Vienna University of

Technology, Austria

Keywords: powder diffraction; aluminophosphate; ionothermal synthesis; ethyltributylphosphonium diethylphosphate; Cyphos 169; redetermination.

CCDC reference: 1965580

Supporting information: this article has supporting information at journals.iucr.org/e

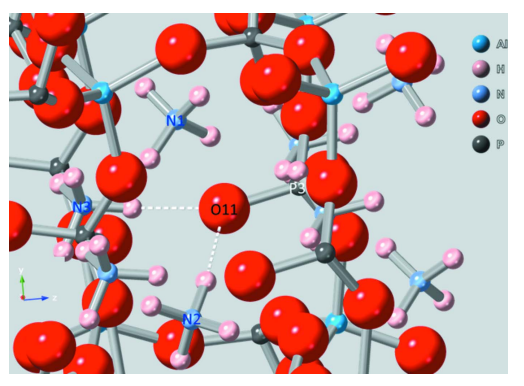

OPEN Ә ACCESS

\section{Structure refinement of $\left(\mathrm{NH}_{4}\right)_{3} \mathrm{Al}_{2}\left(\mathrm{PO}_{4}\right)_{3}$ prepared by ionothermal synthesis in phosphonium based ionic liquids $-\mathrm{a}$ redetermination}

\author{
Christopher P. Nicholas, ${ }^{a *}$ John P.S. Mowat ${ }^{\mathrm{b}}$ and Robert W. Broach ${ }^{\mathrm{b}}$ \\ ${ }^{\mathbf{a}}$ Exploratory Materials and Catalysis Research, Honeywell UOP, Des Plaines IL 60201, USA, and ${ }^{\mathbf{b}}$ Advanced \\ Characterization, Honeywell UOP, Des Plaines IL 60201, USA. *Correspondence e-mail: christopher.nicholas@uop.com
}

After crystallization during ionothermal syntheses in phosphonium-containing ionic liquids, the structure of $\left(\mathrm{NH}_{4}\right)_{3} \mathrm{Al}_{2}\left(\mathrm{PO}_{4}\right)_{3}$ [triammonium dialuminum tris(phosphate)] was refined on the basis of powder $\mathrm{X}$-ray diffraction data from a synchrotron source. $\left(\mathrm{NH}_{4}\right)_{3} \mathrm{Al}_{2}\left(\mathrm{PO}_{4}\right)_{3}$ is a member of the structural family with formula $A_{3} \mathrm{Al}_{2}\left(\mathrm{PO}_{4}\right)_{3}$, where $A$ is a group 1 element, and of which the $\mathrm{NH}_{4}, \mathrm{~K}$, and $\mathrm{Rb}$ forms were previously known. The $\mathrm{NH}_{4}$ form is isostructural with the $\mathrm{K}$ form, and was previously solved from single-crystal X-ray data when the material (SIZ-2) crystallized from a choline-containing eutectic mixture [Cooper et al. (2004). Nature, 430, 1012-1017]. Our independent refinement incorporates $\mathrm{NH}_{4}$ groups and shows that these $\mathrm{NH}_{4}$ groups are hydrogen bonded to framework $\mathrm{O}$ atoms present in rings containing $12 \mathrm{~T}$ sites in a channel along the $c$-axis direction. We describe structural details of $\left(\mathrm{NH}_{4}\right)_{3} \mathrm{Al}_{2}\left(\mathrm{PO}_{4}\right)_{3}$ and discuss differences with respect to isostructural forms.

\section{Chemical context}

Following the discovery of the microporous $\mathrm{AlPO}_{4}-n$ series of materials (Wilson et al., 1982), many efforts have been directed toward the synthesis of novel phases utilizing traditional hydrothermal (Wilson, 2007; Yu \& Xu, 2006) and solvothermal syntheses (Das et al., 2012). Recently, ionothermal synthesis has been added to the stable of synthetic methods. Ionothermal synthesis is an extension of the solvothermal method of synthesis using an ionic liquid as the solvent (replacing, for example, water or ethylene glycol) where a portion of the organic structure-directing agent from a typical zeolite synthesis is derived from the ionic liquid (Morris, 2009). Many new materials have been synthesized by ionothermal synthesis, with new aluminophosphate materials among the most common (Parnham \& Morris, 2007; Xing et al., 2008, 2010).

An important issue in ionothermal synthesis is control of water (Ma et al., 2008). Excess water often leads to synthesis of dense $\mathrm{AlPO}_{4}$ phases such as the one with a tridymite-type of structure, which we observed as well during syntheses utilizing $85 \%_{w t} \mathrm{H}_{3} \mathrm{PO}_{4}$. To control the level of water in the synthesis, thereby allowing easy recycling of the ionic liquid solvent and to intentionally prepare ammonium aluminophosphates, we used $\left(\mathrm{NH}_{4}\right)_{2} \mathrm{HPO}_{4}$ as the phosphorous source in the synthesis. Ammonium is a good structure-directing agent for aluminophosphate frameworks; multiple ammonium aluminum phosphates are known (Byrne et al., 2009; Vaughan et al., 2012). In the current phosphonium-based ionothermal synthesis, the presence of an ammonium cation in the relative absence of water provokes the formation of a $2 / 3 \mathrm{Al} / \mathrm{P}$ framework with 
the formula $\left(\mathrm{NH}_{4}\right)_{3} \mathrm{Al}_{2}\left(\mathrm{PO}_{4}\right)_{3}$. A structurally unrelated compound with the formula $\left(\mathrm{NH}_{4}\right)_{3} \mathrm{Al}_{2}\left(\mathrm{PO}_{4}\right)_{3}$ has previously been synthesized via a solvothermal approach (Medina et al., 2004).

The aluminophosphate database at Jilin ( $\mathrm{Li}$ et al., 2019) currently lists 21 framework structures with a 2:3 ratio of $\mathrm{Al}: \mathrm{P}$. A framework with sub-stoichiometric $\mathrm{Al}$ content is by necessity anionically charged and must be cation-balanced, so most of the known frameworks, such as UT-3, UT-4 and UT-5 (Oliver et al., 1996) are charge-balanced by organoammonium cations. Low-water-content syntheses clearly favor 2:3 compounds as most of the known materials are synthesized from low-water-content preparations.

\section{Structural commentary and survey of related compounds}

The $\left(\mathrm{NH}_{4}\right)_{3} \mathrm{Al}_{2}\left(\mathrm{PO}_{4}\right)_{3}$ phase synthesized here is related to the series of $A_{3} \mathrm{Al}_{2}\left(\mathrm{PO}_{4}\right)_{3}$ materials synthesized via hightemperature solid-state methods (Devi \& Vidyasagar, 2000) with varying monocations on the $A$ site. Additionally, an independent synthesis previously yielded a $\left(\mathrm{NH}_{4}\right)_{3} \mathrm{Al}_{2}\left(\mathrm{PO}_{4}\right)_{3}$ material called SIZ-2 whose structure was solved and refined from single-crystal data (Cooper et al., 2004) and possesses nearly the same structure as refined from the current powder data of $\left(\mathrm{NH}_{4}\right)_{3} \mathrm{Al}_{2}\left(\mathrm{PO}_{4}\right)_{3}$. A polyhedral representation of the crystal structure of $\left(\mathrm{NH}_{4}\right)_{3} \mathrm{Al}_{2}\left(\mathrm{PO}_{4}\right)_{3}$ is shown in Fig. 1. SIZ-2 crystallized from a choline chloride/urea eutectic mixture where decomposition of urea was proposed to be the source of ammonium in the structure. The refinement of Cooper et al. (2004) included the ammonium $\mathrm{N}$ atoms, but made no attempt to find or model the corresponding $\mathrm{H}$ atoms.

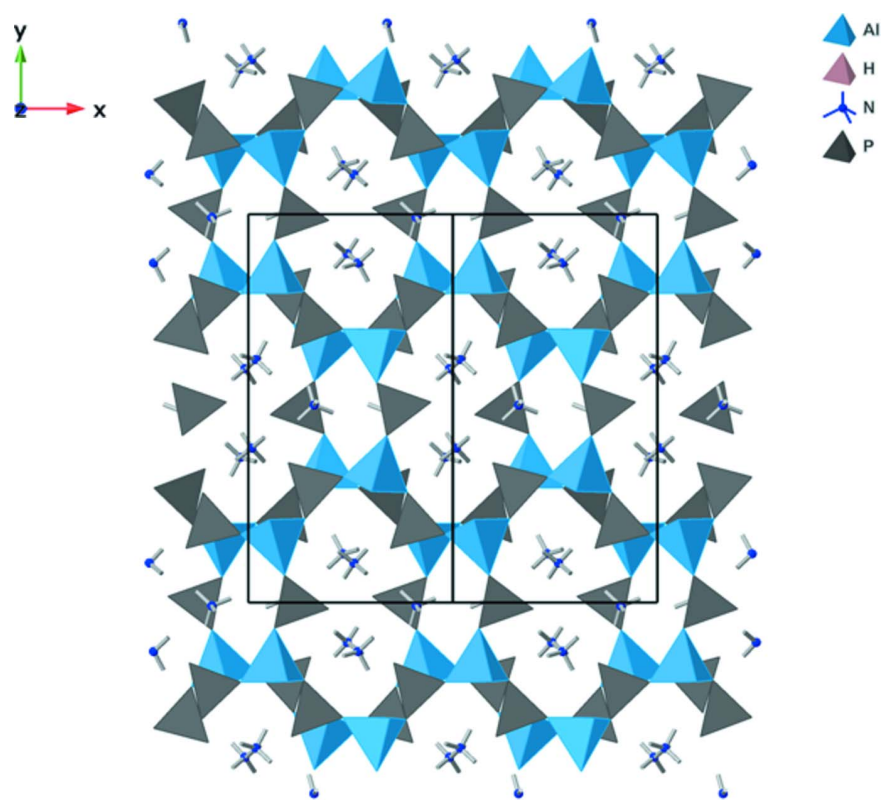

Figure 1

Polyhedral representation of $\left(\mathrm{NH}_{4}\right)_{3} \mathrm{Al}_{2}\left(\mathrm{PO}_{4}\right)_{3}$, showing the overall connectivity and ion channels in the crystal structure. $\mathrm{Al}$ is in the center of blue tetrahedra, $\mathrm{P}$ in gray tetrahedra, and $\mathrm{N}$ is represented by blue spheres.
Table 1

Hydrogen-bond geometry $\left(\AA{ }^{\circ}\right)$.

\begin{tabular}{|c|c|c|c|c|}
\hline$D-\mathrm{H} \cdots A$ & $D-\mathrm{H}$ & $\mathrm{H} \cdots A$ & $D \cdots A$ & $D-\mathrm{H} \cdots A$ \\
\hline $\mathrm{N} 1-\mathrm{H} 11 \cdots \mathrm{O} 9^{\mathrm{i}}$ & $0.95(4)$ & $2.39(4)$ & $3.250(10)$ & $151(3)$ \\
\hline $\mathrm{N} 1-\mathrm{H} 11 \cdots \mathrm{O} 11$ & $0.95(4)$ & $2.35(5)$ & $3.163(8)$ & $143(3)$ \\
\hline $\mathrm{N} 1-\mathrm{H} 12 \cdots \mathrm{O} 1^{\mathrm{ii}}$ & $0.95(4)$ & $1.88(4)$ & $2.791(10)$ & $159(3)$ \\
\hline $\mathrm{N} 1-\mathrm{H} 13 \cdots \mathrm{O} 5$ & $0.95(4)$ & $2.14(4)$ & $2.934(10)$ & $141(3)$ \\
\hline $\mathrm{N} 1-\mathrm{H} 14 \cdots \mathrm{O} 9^{\mathrm{iii}}$ & $0.95(4)$ & $1.83(4)$ & $2.776(9)$ & $173(3)$ \\
\hline $\mathrm{N} 2-\mathrm{H} 21 \cdots \mathrm{O} 5^{\mathrm{iv}}$ & $0.95(4)$ & $1.96(4)$ & $2.896(10)$ & $170(4)$ \\
\hline $\mathrm{N} 2-\mathrm{H} 22 \cdots \mathrm{O} 8^{\mathrm{v}}$ & $0.95(4)$ & $2.31(3)$ & $3.216(10)$ & $158(4)$ \\
\hline $\mathrm{N} 2-\mathrm{H} 23 \cdots \mathrm{O} 9^{\mathrm{iv}}$ & $0.95(4)$ & $1.89(5)$ & $2.738(9)$ & $148(4)$ \\
\hline $\mathrm{N} 2-\mathrm{H} 24 \cdots \mathrm{O} 11^{\mathrm{vi}}$ & $0.96(4)$ & $1.86(4)$ & $2.818(9)$ & $174(5)$ \\
\hline $\mathrm{N} 3-\mathrm{H} 31 \cdots \mathrm{O} 5^{\mathrm{vi}}$ & $0.96(4)$ & $1.97(4)$ & $2.821(9)$ & $147(3)$ \\
\hline $\mathrm{N} 3-\mathrm{H} 32 \cdots \mathrm{O} 11^{\mathrm{vi}}$ & $0.952(15)$ & $1.85(2)$ & $2.728(8)$ & $153(4)$ \\
\hline $\mathrm{N} 3-\mathrm{H} 33 \cdots \mathrm{O} 1^{\mathrm{v}}$ & $0.95(3)$ & $1.90(3)$ & $2.823(9)$ & $164(4)$ \\
\hline $\mathrm{N} 3-\mathrm{H} 34 \cdots \mathrm{O} 12$ & $0.96(3)$ & $2.37(4)$ & $2.925(8)$ & $117(4)$ \\
\hline
\end{tabular}

Symmetry codes: (i) $x, y, z+1$; (ii) $x-\frac{1}{2},-y+\frac{1}{2}, z+1$; (iii) $-x,-y+1, z+\frac{1}{2}$; (iv) $x+1, y, z ;$ (v) $x+\frac{1}{2},-y+\frac{1}{2}, z$; (vi) $-x+1,-y+1, z-\frac{1}{2}$.

Devi \& Vidyasagar (2000) utilized Li, Na, K, Rb, Cs, and Tl as the $A$ cation and succeeded in crystallizing compounds with $A=\mathrm{Na}, \mathrm{K}, \mathrm{Rb}, \mathrm{Tl}$. The thallium derivative yielded a completely different structure with trigonal-bipyramidal coordination of Al. The $A=\mathrm{Na}$ structure was not solved, but apparently crystallizes in an unrelated orthorhombic spacegroup type from that observed for $A=\mathrm{K}$, Rb in their work, and for $A=\mathrm{NH}_{4}$ here. Devi \& Vidyasagar (2000) utilized $\left(\mathrm{NH}_{4}\right)_{2} \mathrm{HPO}_{4}$ as the phosphate source in their high-temperature preparations of $A_{3} \mathrm{Al}_{2}\left(\mathrm{PO}_{4}\right)_{3}$, but did not obtain $\left(\mathrm{NH}_{4}\right)_{3} \mathrm{Al}_{2}\left(\mathrm{PO}_{4}\right)_{3}$, likely due to the volatility of $\mathrm{NH}_{3}$ at high temperatures.

As in the $\mathrm{K}$ and $\mathrm{Rb}$ forms of the $A_{3} \mathrm{Al}_{2}\left(\mathrm{PO}_{4}\right)_{3}$ series, aluminum and phosphorus are both tetrahedrally coordinated and connected through corners throughout the $\left(\mathrm{NH}_{4}\right)_{3} \mathrm{Al}_{2}\left(\mathrm{PO}_{4}\right)_{3}$ structure. The $\mathrm{NH}_{4}{ }^{+}$cations reside in a channel along the $c$-axis direction made from a $12 T$-site ring of alternating $\mathrm{AlO}_{4}$ and $\mathrm{PO}_{4}$ tetrahedra (Fig. 2). The $\mathrm{NH}_{4}^{+}$ groups occupy the available space and none of the ionic liquid

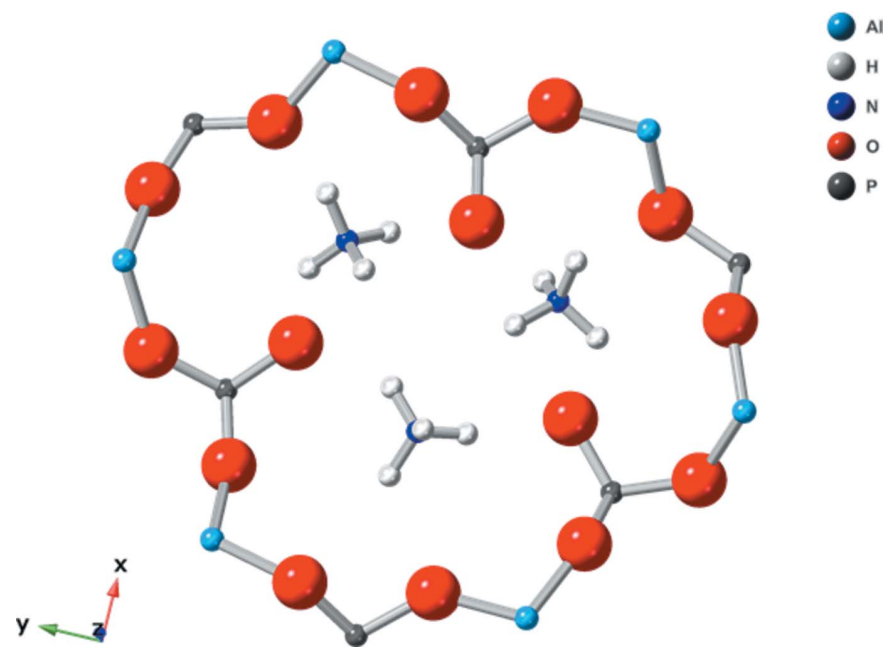

Figure 2

Ball and stick representation of $\left(\mathrm{NH}_{4}\right)_{3} \mathrm{Al}_{2}\left(\mathrm{PO}_{4}\right)_{3}$ showing the 12membered ring with three phosphate groups protruding inward with close contact to ammonium cations. 
Table 2

Key atomic distances $(\AA)$ in related $A_{3} \mathrm{Al}_{2}\left(\mathrm{PO}_{4}\right)_{3}$ structures.

\begin{tabular}{llllll}
\hline Compound & $\mathrm{O} 11-A 1$ & $\mathrm{O} 11-A 2$ & $\mathrm{O} 11-A 3$ & O11-P3 & Reference \\
\hline$\left(\mathrm{NH}_{4}\right)_{3} \mathrm{Al}_{2}\left(\mathrm{PO}_{4}\right)_{3}$ & 3.162 & 2.818 & 2.727 & 1.487 & This work \\
$\mathrm{SIZ}-2\left(A=\mathrm{NH}_{4}\right)$ & 3.090 & 2.834 & 2.688 & 1.496 & Cooper et al. (2004) \\
$\mathrm{K}_{3} \mathrm{Al}_{2}\left(\mathrm{PO}_{4}\right)_{3}$ & 2.754 & 2.824 & 2.722 & 1.487 & Devi \& Vidyasagar (2000) \\
$\mathrm{K}_{3} \mathrm{Al}_{2}\left(\mathrm{AsO}_{4}\right)_{2}\left(\mathrm{PO}_{4}\right)$ & 3.025 & 2.743 & 2.621 & 1.673 & Boughzala et al. (1997) \\
\hline
\end{tabular}

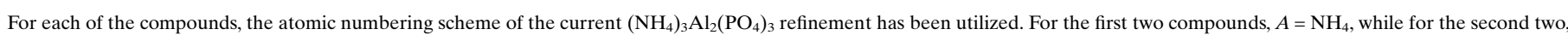
$A=\mathrm{K}$. For the As-containing compound, the $\mathrm{P} 3$ site is reported to have the highest occupancy of As at 0.86 .

solvent is present within the pores of the $\left(\mathrm{NH}_{4}\right)_{3} \mathrm{Al}_{2}\left(\mathrm{PO}_{4}\right)_{3}$ framework. Without the $\mathrm{NH}_{4}{ }^{+}$groups, the structure would have $24 \%$ void volume. The framework is triply negatively charged and charge-balanced by the ammonium cations. Three of the six phosphate groups in the ring protrude inward such that the closest contact distance between the $\mathrm{H}$ atom of an ammonium group and the $\mathrm{O}$ atom of the nearest phosphate is between 1.83 and $1.87 \AA$, indicating significant hydrogenbonding interactions. The full range of $\mathrm{H}$. . O hydrogen-bond lengths is between 1.83 and $1.97 \AA$ (Table 1 ).

Crystallizing in space-group type $P n a 2_{1},\left(\mathrm{NH}_{4}\right)_{3} \mathrm{Al}_{2}\left(\mathrm{PO}_{4}\right)_{3}$ is isostructural to, but with a slightly larger unit cell than the $\mathrm{K}$ form synthesized by Devi \& Vidyasagar (2000). Lattice expansion of $\sim 0.1-0.2 \AA$ occurs along each of the three axes, leading to an overall $6.6 \%$ increase in cell volume from 1245 to $1327 \AA^{3}$. A lattice expansion is no surprise as the ionic radius of $\mathrm{NH}_{4}{ }^{+}$is between 1.4 and $1.67 \AA$ depending on the coordination number (Sidey, 2016). This is slightly larger than the reported 1.37 to $1.55 \AA$ range for $\mathrm{K}^{+}$(Shannon, 1976). Much of the relative lattice expansion for $\left(\mathrm{NH}_{4}\right)_{3} \mathrm{Al}_{2}\left(\mathrm{PO}_{4}\right)_{3}$ occurs along the $a$ and $c$ axes. Tilting of tetrahedra accounts for a significantly smaller expansion of the long $b$ axis. In addition, an isostructural K/As form is also known where two-thirds of the phosphate groups have been replaced by arsenate (Boughzala et al., 1997). Arsenate included on the phosphate sites increases the cell volume to $1307 \AA^{3}$, just smaller than that recorded here for $\left(\mathrm{NH}_{4}\right)_{3} \mathrm{Al}_{2}\left(\mathrm{PO}_{4}\right)_{3}$. The pure arsenate form $\mathrm{K}_{3} \mathrm{Al}_{2}\left(\mathrm{AsO}_{4}\right)_{3}$ was reported by Stöger \& Weil (2012),

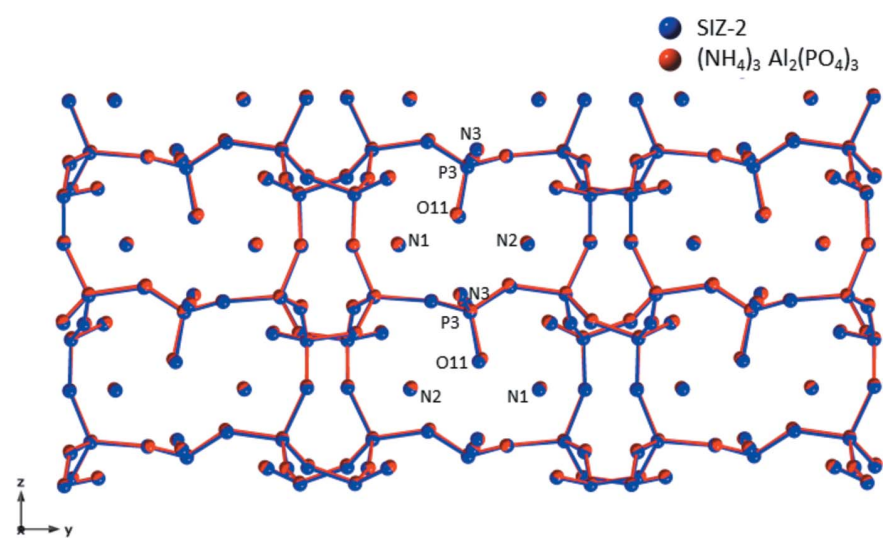

Figure 3

Atomic position overlay plot of SIZ-2 (blue) and $\left(\mathrm{NH}_{4}\right)_{3} \mathrm{Al}_{2}\left(\mathrm{PO}_{4}\right)_{3}$ (red) showing that most atom positions are within $0.03 \AA$ of each other. The most significant difference is in the $\mathrm{O} 11$ position. which has a cell volume of $1328 \AA^{3}$, essentially equivalent to that here.

An overlay plot of atomic positions of $\left(\mathrm{NH}_{4}\right)_{3} \mathrm{Al}_{2}\left(\mathrm{PO}_{4}\right)_{3}$ (red) versus SIZ-2 (blue) shows that although the independent refinements of the two $\left(\mathrm{NH}_{4}\right)_{3} \mathrm{Al}_{2}\left(\mathrm{PO}_{4}\right)_{3}$ materials were performed via different methods at different temperatures, most atom positions are similar, with no more than about 0.004 fractional position differences along the $a$ or $c$ axes (for these axes, about $0.03-0.04 \AA$, Fig. 3). One area stands out in the $A_{3} \mathrm{Al}_{2}\left(\mathrm{PO}_{4}\right)_{3}$ series. Fig. 4 shows the key area surrounding $\mathrm{O} 11$ where the largest position movement is observed in the two independent refinements of $\left(\mathrm{NH}_{4}\right)_{3} \mathrm{Al}_{2}\left(\mathrm{PO}_{4}\right)_{3}$.

The $\mathrm{P} 3-\mathrm{O} 11$ bond is always among the shortest $\mathrm{P}-\mathrm{O}$ bonds found in the crystal structure, here at 1.487 (5) $\AA$. Two clusters of $\mathrm{P}-\mathrm{O}$ bond lengths occur; one at about $1.49 \AA$ and another at $1.55 \AA$. These distances are relatively typical for aluminophosphates (Richardson \& Vogt, 1992; Wei et al., 2012). Each of the $\mathrm{O}$ atoms protruding into the pore possess short $\mathrm{P}-\mathrm{O}$ bonds and hydrogen bonds to two ammonium ions (Table 1). In particular, N2, N3, O11, and P3 are effectively in a plane so that with the hydrogen bonding present in our refined model from $\mathrm{N} 3$ and $\mathrm{N} 2$ through the attached $\mathrm{H}$ atoms to $\mathrm{O} 11, \mathrm{O} 11$ moves closer to P3 while N2 and N3 move slightly further away versus the positions in the SIZ-2 refinement. Table 2 shows respective $\mathrm{O}-A$ and $\mathrm{P}-\mathrm{O}$ distances for the

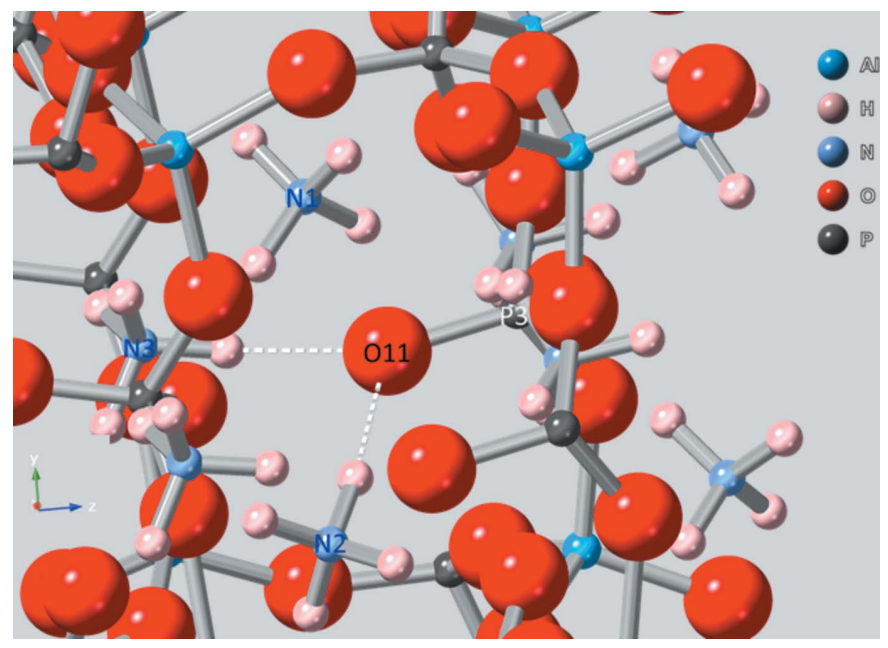

Figure 4

Ball and stick representation of the key area surrounding O11 where the largest position movement takes place in the two independent refinements of $\left(\mathrm{NH}_{4}\right)_{3} \mathrm{Al}_{2}\left(\mathrm{PO}_{4}\right)_{3}$. 


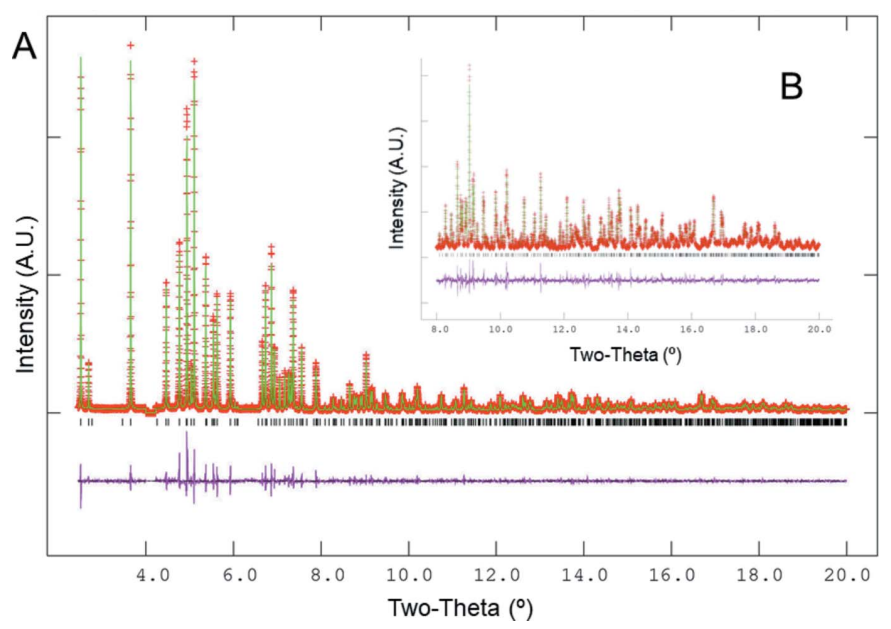

Figure 5

XRD pattern $(\lambda=0.373811 \AA)$ of $\left(\mathrm{NH}_{4}\right)_{3} \mathrm{Al}_{2}\left(\mathrm{PO}_{4}\right)_{3}$ synthesized ionothermally in ethyl tributylphosphonium diethylphosphate and Rietveld residuals following structure refinement. Part A shows the fit to the overall pattern, and inset B shows the fit to high-angle regions.

four isostructural $A_{3} \mathrm{Al}_{2}\left(\mathrm{PO}_{4}\right)_{3}$ compounds. Other bond lengths and angles are otherwise relatively unremarkable versus other members of the structural class although we note that $\mathrm{As} / \mathrm{P}-\mathrm{O}$ distances are longer than $\mathrm{P}-\mathrm{O}$ as expected.

$\mathrm{Rb}_{3} \mathrm{Al}_{2}\left(\mathrm{PO}_{4}\right)_{3}$ is structurally related to the $\mathrm{NH}_{4}$ and $\mathrm{K}$ forms, but crystallizes in a higher symmetry space-group type $\left(C m c 2_{1}\right)$, accompanied with higher overall coordination numbers around $\mathrm{Rb}^{+}$and a mirror plane perpendicular to $a$. The ionic radius of $\mathrm{Rb}^{+}$is similar to that of $\mathrm{NH}_{4}{ }^{+}$, reported as 1.52-1.63 A (Shannon, 1976). Lithium and cesium forms of the series have not yet been synthesized, likely because of the relatively small and large, respectively, ionic radii versus those of the fitting $A$ cations. Our initial attempts at ion-exchange of $\left(\mathrm{NH}_{4}\right)_{3} \mathrm{Al}_{2}\left(\mathrm{PO}_{4}\right)_{3}$ with $\mathrm{LiNO}_{3}$ or $\mathrm{CsNO}_{3}$ in aqueous solution to form the $\mathrm{Li}$ or $\mathrm{Cs}$ form failed, with partial structural degradation and no ion-exchange observed.

\section{Synthesis and crystallization}

In a typical preparation, $1.65 \mathrm{~g}\left(\mathrm{NH}_{4}\right)_{2} \mathrm{HPO}_{4}$ was added to a $125 \mathrm{ml}$ polytetrafluoroethene (PTFE) lined autoclave containing $24.02 \mathrm{~g}$ of ethyl tri(butyl)phosphonium diethyl phosphate. The mixture was stirred at room temperature for $2 \mathrm{~min}$. To this mixture were added $0.49 \mathrm{~g}$ of $\mathrm{Al}(\mathrm{OH})_{3}$, and the contents were stirred at room temperature for $2 \mathrm{~min}$. The contents of the autoclave were digested at $423 \mathrm{~K}$ for $24 \mathrm{~h}$ prior to isolating the product by filtration. Analytical results show this material has a molar ratio $\mathrm{Al}: \mathrm{P}$ of 0.725 . The X-ray diffraction pattern is shown in Fig. 5. Scanning electron microscopy (SEM) revealed agglomerated stacks of irregularly shaped blocky crystals of from $500 \mathrm{~nm}$ to $2-4 \mu \mathrm{m}$ in length (Fig. 6). Calcination of $\left(\mathrm{NH}_{4}\right)_{3} \mathrm{Al}_{2}\left(\mathrm{PO}_{4}\right)_{3}$ at temperatures of $773 \mathrm{~K}$ or higher causes the formation of an $\mathrm{AlPO}_{4}$
Table 3

Experimental details.

Crystal data

Chemical formula

$M_{\mathrm{r}}$

Crystal system, space group

Temperature (K)

$a, b, c(\AA)$

$V\left(\AA^{3}\right)$

$Z$

Radiation type

$\mu\left(\mathrm{mm}^{-1}\right)$

Specimen shape, size $(\mathrm{mm})$

$\left(\mathrm{NH}_{4}\right)_{3} \mathrm{Al}_{2}\left(\mathrm{PO}_{4}\right)_{3}$

392.99

Orthorhombic, Pna2 1

100

8.98884 (6), 17.01605 (10), $8.67653(5)$

$1327.11(2)$

4

Synchrotron, $\lambda=0.373811 \AA$

0.12

Cylinder, $0.70 \times 0.70$

Data collection

Diffractometer

Specimen mounting

Data collection mode

Scan method

$2 \theta$ values $\left(^{\circ}\right)$

11BM synchrotron

Capillary

Transmission

Continuous

$2 \theta_{\min }=2.45,2 \theta_{\max }=20$,

Refinement

$R$ factors and goodness of fit

$2 \theta_{\text {step }}=0.001$

No. of parameters

No. of restraints

$\mathrm{H}$-atom treatment

$R_{\mathrm{p}}=0.082, R_{\mathrm{wp}}=0.101$, $R_{\text {exp }}=0.060, R\left(F^{2}\right)=0.03552$,

${ }_{95}{ }^{\chi}$ $\chi^{2}=2.856$

$\mathrm{H}$ atoms treated by a mixture of independent and constrained refinement

$(\Delta / \sigma)_{\max }$ 0.17

Computer programs: local program at 11BM, GSAS (Larson \& Von Dreele, 2000), coordinates from an isotypic structure, CrystalMaker (Palmer, 2005), publCIF (Westrip, 2010).

phase with a tridymite-type structure. Ethyl tributyl phosphonium diethyl phosphate (Cyphos 169) was acquired from Cytec; aluminum hydroxide was acquired from Pfaltz and Bauer.

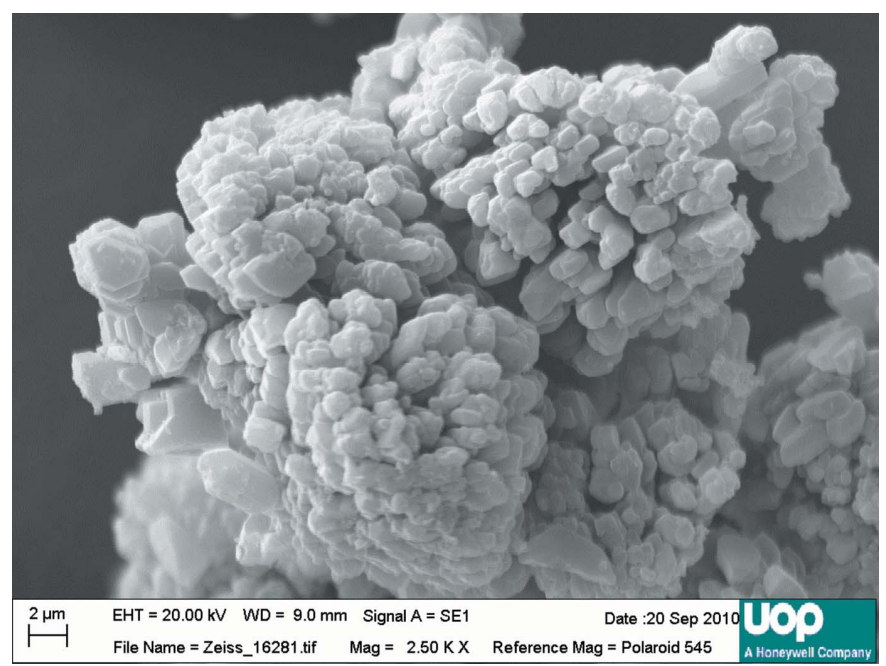

Figure 6

SEM image of polycrystalline $\left(\mathrm{NH}_{4}\right)_{3} \mathrm{Al}_{2}\left(\mathrm{PO}_{4}\right)_{3}$ synthesized ionothermally in ethyl tributylphosphonium diethyl phosphate and used for structure refinement. 


\section{Refinement}

Crystal data, data collection and structure refinement details are summarized in Table 3. Following initial survey scans on in-house $\mathrm{Cu}$ source powder XRD instruments, final data were acquired from samples packed in thin glass capillaries on 11-BM at the Advanced Photon Source at Argonne National Laboratory. Starting atomic positions for the refinement were adapted from the literature examples. Starting positions for the ammonium cations were located in a difference-Fourier map and subsequently refined using GSAS (Larson \& Von Dreele, 2000) as tetrahedral rigid bodies with $\mathrm{N}-\mathrm{H}$ bond lengths held at $0.9526 \AA$ and tetrahedrality enforced, leading to $\mathrm{H} \cdots \mathrm{H}$ distances of $1.5556 \AA$. No soft constraints were applied to the framework positions. All atoms in the structure were refined with a common $U_{\text {iso }}$ parameter. Two low-intensity reflections in the region $4.00-4.22^{\circ} / 2 \theta$ were excluded from the refinement as belonging to an impurity phase after assessment of multiple $\left(\mathrm{NH}_{4}\right)_{3} \mathrm{Al}_{2}\left(\mathrm{PO}_{4}\right)_{3}$ batches. Refinement trials with a higher symmetry model (space-group type $C m c 2_{1}$ ) were attempted but showed poor agreement with the experimental data, with $R_{\text {wp }}>0.16$.

\section{Acknowledgements}

We thank UOP for funding and allowing this publication. Use of the Advanced Photon Source at Argonne National Laboratory was supported by the US Department of Energy, Office of Science, Office of Basic Energy Sciences, under Contract No. DE-AC02-06CH11357. We acknowledge E. Fulmer, C. L. Nicholas and S. T. Wilson for helpful discussions and J. F. Kotek and A. Stolarski for the ICP and SEM results.

\section{Funding information}

Funding for this research was provided by: UOP LLC.

\section{References}

Boughzala, H., Driss, A. \& Jouini, T. (1997). Acta Cryst. C53, 3-5. Byrne, P. J., Warren, J. E., Morris, R. E. \& Ashbrook, S. E. (2009). Solid State Sci. 11, 1001-1006.

Cooper, E. R., Andrews, C. D., Wheatley, P. S., Webb, P. B., Wormald, P. \& Morris, R. E. (2004). Nature, 430, 1012-1016.

Das, S. K., Bhunia, M. K. \& Bhaumik, A. (2012). Microporous Mesoporous Mater. 155, 258-264.

Devi, R. N. \& Vidyasagar, K. (2000). Inorg. Chem. 39, 2391-2396.

Larson, A. C. \& Von Dreele, R. B. (2000). General Structure Analysis System (GSAS). Report LAUR, 86-748 Los Alamos National Laboratory, New Mexico, USA.

Li, Y., Yu, J. \& Xu, R. (2019). URL of AlPO database (freely accessible): http://mezeopor.jlu.edu.cn/alpo/alpo.jsp

Ma, H., Tian, Z., Xu, R., Wang, B., Wei, Y., Wang, L., Xu, Y., Zhang, W. \& Lin, L. (2008). J. Am. Chem. Soc. 130, 8120-8121.

Medina, M. E., Iglesias, M., Gutiérrez-Puebla, E. \& Monge, M. A. (2004). J. Mater. Chem. 14, 845-850.

Morris, R. E. (2009). Chem. Commun. pp. 2990-2998.

Oliver, S., Kuperman, A., Lough, A. \& Ozin, G. A. (1996). Chem. Commun. pp. 1761-1762.

Palmer, D. (2005). CrystalMaker. CrystalMaker Software Ltd, Yarnton, England.

Parnham, E. \& Morris, R. E. (2007). Acc. Chem. Res. 40, 10051013.

Richardson, J. W. \& Vogt, E. T. C. (1992). Zeolites, 12, 13-19.

Shannon, R. D. (1976). Acta Cryst. A32, 751-767.

Sidey, V. (2016). Acta Cryst. B72, 626-633.

Stöger, B. \& Weil, M. (2012). Acta Cryst. E68, i15.

Vaughan, D. E. W., Yennawar, H. P. \& Perrotta, A. J. (2012). Microporous Mesoporous Mater. 153, 18-23.

Wei, Y., Marler, B., Zhang, L., Tian, Z., Graetsch, H. \& Gies, H. (2012). Dalton Trans. 41, 12408-12415.

Westrip, S. P. (2010). J. Appl. Cryst. 43, 920-925.

Wilson, S. T. (2007). Introduction to Zeolite Science and Practice, 3rd ed, edited by J. Čejka, H. van Bekkum, A. Corma, \& F. Schüth, ch. 4, pp. 105-135. Amsterdam: Elsevier.

Wilson, S. T., Lok, B. M., Messina, C. A., Cannan, T. R. \& Flanigen, E. M. (1982). J. Am. Chem. Soc. 104, 1146-1147.

Xing, H., Li, J., Yan, W., Chen, P., Jin, Z., Yu, J., Dai, S. \& Xu, R. (2008). Chem. Mater. 20, 4179-4181.

Xing, H., Li, Y., Su, T., Xu, J., Yang, W., Zhu, E., Yu, J. \& Xu, R. (2010). Dalton Trans. 39, 1713-1715.

Yu, J. \& Xu, R. (2006). Chem. Soc. Rev. 35, 593-604. 


\section{supporting information}

Acta Cryst. (2019). E75, 1897-1901［https://doi.org/10.1107/S2056989019015330]

Structure refinement of $\left(\mathrm{NH}_{4}\right)_{3} \mathrm{Al}_{2}\left(\mathrm{PO}_{4}\right)_{3}$ prepared by ionothermal synthesis in phosphonium based ionic liquids - a redetermination

\section{Christopher P. Nicholas, John P.S. Mowat and Robert W. Broach}

\section{Computing details}

Data collection: local program at 11BM; data reduction: GSAS (Larson \& Von Dreele, 2000); program(s) used to solve structure: coordinates from an isotypic structure; program(s) used to refine structure: GSAS (Larson \& Von Dreele, 2000); molecular graphics: CrystalMaker (Palmer, 2005); software used to prepare material for publication: publCIF (Westrip, 2010).

Triammonium dialuminium tris(phosphate)

\section{Crystal data}

$\left(\mathrm{NH}_{4}\right)_{3} \mathrm{Al}_{2}\left(\mathrm{PO}_{4}\right)_{3}$

$M_{r}=392.99$

Orthorhombic, Pna2 $_{1}$

Hall symbol: P 2c -2n

$a=8.98884(6) \AA$

$b=17.01605(10) \AA$

$c=8.67653(5) \AA$

$$
\begin{aligned}
& V=1327.11(2) \AA^{3} \\
& Z=4 \\
& \text { Synchrotron radiation, } \lambda=0.373811 \AA \\
& \mu=0.12 \mathrm{~mm}^{-1} \\
& T=100 \mathrm{~K} \\
& \text { white } \\
& \text { cylinder, } 0.70 \times 0.70 \mathrm{~mm}
\end{aligned}
$$

\section{Data collection}

11BM_synchrotron

diffractometer

Specimen mounting: capillary

Data collection mode: transmission

Scan method: continuous

$2 \theta_{\min }=2.45^{\circ}, 2 \theta_{\max }=20^{\circ}, 2 \theta_{\text {step }}=0.001^{\circ}$ 


\section{Refinement}

Least-squares matrix: full

$R_{\mathrm{p}}=0.082$

$R_{\text {wp }}=0.101$

$R_{\text {exp }}=0.060$

$R\left(F^{2}\right)=0.03552$

49495 data points
Profile function: CW Profile function number 4 with 18 terms Pseudovoigt profile coefficients as parameterized in P. Thompson, D.E. Cox \& J.B. Hastings (1987). J. Appl. Cryst.,20,79-83. Asymmetry correction of L.W. Finger, D.E. Cox \& A. P. Jephcoat (1994). J. Appl.

Cryst.,27,892-900. Microstrain broadening by P.W. Stephens, (1999). J. Appl.

Cryst.,32,281-289. $\# 1(\mathrm{GU})=1.163 \# 2(\mathrm{GV})=$ $-0.126 \# 3(\mathrm{GW})=0.063 \# 4(\mathrm{GP})=0.000 \# 5(\mathrm{LX})$

$=0.143 \# 6(\mathrm{ptec})=-0.01 \# 7$ (trns) $=0.00 \# 8(\mathrm{shft})$

$=0.0000 \# 9(\mathrm{sfec})=0.00 \# 10(\mathrm{~S} / \mathrm{L})=0.0011$

$\# 11(\mathrm{H} / \mathrm{L})=0.0011 \# 12(\mathrm{eta})=0.7694 \# 13(\mathrm{~S} 400$ )$=1.1 \mathrm{E}-01 \# 14(\mathrm{~S} 040)=2.8 \mathrm{E}-03 \# 15(\mathrm{~S} 004)=$ $1.0 \mathrm{E}-01 \# 16(\mathrm{~S} 220)=1.3 \mathrm{E}-02 \# 17(\mathrm{~S} 202)=$ $-9.0 \mathrm{E}-03 \# 18(\mathrm{~S} 022)=6.9 \mathrm{E}-03$ Peak tails are ignored where the intensity is below 0.0010 times the peak Aniso. broadening axis 1.00 .0 0.0

95 parameters

20 restraints

$\mathrm{H}$ atoms treated by a mixture of independent and constrained refinement

$(\Delta / \sigma)_{\max }=0.17$

Background function: GSAS Background function number 1 with 11 terms. Shifted Chebyshev function of 1st kind 1: 111.0862 : -42.2923 3: 17.4011 4: -1.76183 5: -7.25556 6: 2.97020 7: 2.60010 8: -3.84672 9: 5.91765 10: -3.48127 11: 1.19076

Fractional atomic coordinates and isotropic or equivalent isotropic displacement parameters $\left(\AA^{2}\right)$

\begin{tabular}{lllll}
\hline & $x$ & $y$ & $z$ & $U_{\text {iso }}^{*} / U_{\text {eq }}$ \\
\hline P1 & $0.1689(3)$ & $0.21458(16)$ & $-0.0138(5)$ & $0.0086(3)^{*}$ \\
P2 & $0.3100(3)$ & $0.29952(16)$ & $0.4927(5)$ & $0.0086(3)^{*}$ \\
P3 & $0.2594(3)$ & $0.5033(2)$ & 0.0861 & $0.0086(3)^{*}$ \\
A11 & $0.3631(4)$ & $0.33375(18)$ & $0.1361(5)$ & $0.0086(3)^{*}$ \\
A12 & $0.1295(4)$ & $0.17048(19)$ & $0.6462(5)$ & $0.0086(3)^{*}$ \\
O1 & $0.2886(7)$ & $0.1552(3)$ & $0.0117(8)$ & $0.0086(3)^{*}$ \\
O2 & $0.0384(8)$ & $0.2046(3)$ & $0.1014(8)$ & $0.0086(3)^{*}$ \\
O3 & $0.2289(7)$ & $0.3006(3)$ & $0.0100(8)$ & $0.0086(3)^{*}$ \\
O4 & $0.1017(7)$ & $0.2138(4)$ & $0.8252(8)$ & $0.0086(3)^{*}$ \\
O5 & $0.1953(7)$ & $0.3602(3)$ & $0.5464(8)$ & $0.0086(3)^{*}$ \\
O6 & $0.4625(7)$ & $0.3234(3)$ & $0.5425(8)$ & $0.0086(3)^{*}$ \\
O7 & $0.2776(8)$ & $0.2165(3)$ & $0.5518(7)$ & $0.0086(3)^{*}$ \\
O8 & $0.3087(7)$ & $0.2962(4)$ & $0.3126(8)$ & $0.0086(3)^{*}$ \\
O9 & $0.1072(5)$ & $0.4838(3)$ & $0.1404(8)$ & $0.0086(3)^{*}$ \\
O10 & $0.3228(7)$ & $0.5700(4)$ & $0.1747(7)$ & $0.0086(3)^{*}$ \\
O11 & $0.2604(6)$ & $0.5218(3)$ & $0.9186(6)$ & $0.0086(3)^{*}$ \\
O12 & $0.3716(7)$ & $0.4348(3)$ & $0.1188(9)$ & $0.0086(3)^{*}$
\end{tabular}




$\begin{array}{lllll}\mathrm{N} 1 & 0.0164(8) & 0.3978(4) & 0.8194(9) & 0.0086(3)^{*} \\ \mathrm{H} 11 & 0.076(5) & 0.425(3) & 0.893(4) & 0.0086(3)^{*} \\ \mathrm{H} 12 & -0.058(4) & 0.368(3) & 0.871(5) & 0.0086(3)^{*} \\ \mathrm{H} 13 & 0.077(5) & 0.364(2) & 0.760(5) & 0.0086(3)^{*} \\ \mathrm{H} 14 & -0.030(5) & 0.435(2) & 0.753(5) & 0.0086(3)^{*} \\ \mathrm{~N} 2 & 0.9630(8) & 0.3743(4) & 0.3168(9) & 0.0086(3)^{*} \\ \mathrm{H} 21 & 1.036(4) & 0.363(3) & 0.393(5) & 0.0086(3)^{*} \\ \mathrm{H} 22 & 0.915(6) & 0.3268(16) & 0.287(6) & 0.0086(3)^{*} \\ \mathrm{H} 23 & 1.009(5) & 0.397(3) & 0.229(4) & 0.0086(3)^{*} \\ \mathrm{H} 24 & 0.891(5) & 0.410(3) & 0.358(6) & 0.0086(3)^{*} \\ \mathrm{~N} 3 & 0.6786(6) & 0.4917(4) & 0.1118(7) & 0.0086(3)^{*} \\ \mathrm{H} 31 & 0.755(4) & 0.530(2) & 0.095(6) & 0.0086(3)^{*} \\ \mathrm{H} 32 & 0.668(5) & 0.483(3) & 0.2196(14) & 0.0086(3)^{*} \\ \mathrm{H} 33 & 0.704(5) & 0.4438(18) & 0.062(5) & 0.0086(3)^{*} \\ \mathrm{H} 34 & 0.587(3) & 0.511(3) & 0.071(5) & 0.0086(3)^{*}\end{array}$

Geometric parameters $\left(A,{ }^{\circ}\right)$

\begin{tabular}{|c|c|c|c|}
\hline P1-A11 & $2.975(5)$ & $\mathrm{O} 3-\mathrm{P} 1$ & $1.573(6)$ \\
\hline $\mathrm{P} 1-\mathrm{A} 12^{\mathrm{i}}$ & $3.064(5)$ & $\mathrm{O} 3-\mathrm{A} 11$ & $1.724(7)$ \\
\hline $\mathrm{P} 1-\mathrm{O} 1$ & $1.493(6)$ & $\mathrm{O} 4-\mathrm{P} 1^{\mathrm{iv}}$ & $1.522(7)$ \\
\hline $\mathrm{P} 1-\mathrm{O} 2$ & $1.550(7)$ & $\mathrm{O} 4-\mathrm{A} 12$ & $1.737(7)$ \\
\hline $\mathrm{P} 1-\mathrm{O} 3$ & $1.573(6)$ & $\mathrm{O} 5-\mathrm{P} 2$ & $1.532(6)$ \\
\hline $\mathrm{P} 1-O 4^{\mathrm{i}}$ & $1.522(7)$ & $\mathrm{O} 5-\mathrm{H} 21^{\mathrm{viii}}$ & $1.953(13)$ \\
\hline $\mathrm{P} 2-\mathrm{A} 12$ & $3.038(4)$ & $\mathrm{O} 5-\mathrm{H} 31^{\mathrm{ix}}$ & $1.97(3)$ \\
\hline $\mathrm{P} 2-\mathrm{O} 5$ & $1.532(6)$ & $\mathrm{O} 6-\mathrm{P} 2$ & $1.493(7)$ \\
\hline $\mathrm{P} 2-\mathrm{O} 6$ & $1.493(7)$ & $\mathrm{O} 6-\mathrm{A} 12^{\mathrm{iii}}$ & $1.753(7)$ \\
\hline $\mathrm{P} 2-\mathrm{O} 7$ & $1.532(6)$ & $\mathrm{O} 7-\mathrm{P} 2$ & $1.532(6)$ \\
\hline $\mathrm{P} 2-\mathrm{O} 8$ & $1.563(6)$ & $\mathrm{O} 7-\mathrm{A} 12$ & $1.748(7)$ \\
\hline P3-Al1 & $3.062(5)$ & $\mathrm{O} 8-\mathrm{P} 2$ & $1.563(6)$ \\
\hline $\mathrm{P} 3-\mathrm{A} 12^{\mathrm{ii}}$ & $3.060(5)$ & $\mathrm{O} 8-\mathrm{A} 11$ & $1.730(7)$ \\
\hline P3-O9 & $1.484(5)$ & $\mathrm{O} 9-\mathrm{P} 3$ & $1.484(5)$ \\
\hline $\mathrm{P} 3-\mathrm{O} 10$ & $1.485(6)$ & O9-H14 & $1.828(10)$ \\
\hline $\mathrm{P} 3-\mathrm{O} 11^{\mathrm{i}}$ & $1.487(5)$ & $\mathrm{O} 9-\mathrm{H} 23^{\text {viii }}$ & $1.88(3)$ \\
\hline $\mathrm{P} 3-\mathrm{O} 12$ & $1.567(6)$ & $\mathrm{O} 10-\mathrm{P} 3$ & $1.485(6)$ \\
\hline $\mathrm{A} 11-\mathrm{P} 1$ & $2.975(5)$ & $\mathrm{O} 10-\mathrm{A} 12^{\mathrm{ii}}$ & $1.780(7)$ \\
\hline $\mathrm{A} 11-\mathrm{P} 3$ & $3.062(5)$ & $\mathrm{O} 11-\mathrm{P} 3^{\mathrm{iv}}$ & $1.487(5)$ \\
\hline $\mathrm{A} 11-\mathrm{O} 2^{\mathrm{iii}}$ & $1.732(7)$ & $\mathrm{O} 11-\mathrm{H} 24^{\mathrm{ix}}$ & $1.868(10)$ \\
\hline $\mathrm{A} 11-\mathrm{O} 3$ & $1.724(7)$ & $\mathrm{O} 11-\mathrm{H} 32^{\mathrm{ix}}$ & $1.84(2)$ \\
\hline $\mathrm{Al1}-\mathrm{O} 8$ & $1.730(7)$ & $\mathrm{O} 12-\mathrm{P} 3$ & $1.567(6)$ \\
\hline $\mathrm{A} 11-\mathrm{O} 12$ & $1.727(6)$ & $\mathrm{O} 12-\mathrm{Al1}$ & $1.727(6)$ \\
\hline $\mathrm{A} 12-\mathrm{P} 1^{\text {iv }}$ & $3.064(5)$ & $\mathrm{N} 1-\mathrm{H} 11$ & $0.9526(1)$ \\
\hline $\mathrm{A} 12-\mathrm{P} 2$ & $3.038(4)$ & $\mathrm{N} 1-\mathrm{H} 12$ & $0.9526(1)$ \\
\hline $\mathrm{A} 12-\mathrm{P} 3^{\mathrm{v}}$ & $3.060(5)$ & $\mathrm{N} 1-\mathrm{H} 13$ & $0.9526(1)$ \\
\hline $\mathrm{A} 12-\mathrm{O} 4$ & $1.737(7)$ & $\mathrm{N} 1-\mathrm{H} 14$ & 0.9526 \\
\hline $\mathrm{A} 12-\mathrm{O}^{\mathrm{vi}}$ & $1.753(7)$ & $\mathrm{N} 2-\mathrm{H} 21$ & $0.9526(1)$ \\
\hline $\mathrm{A} 12-\mathrm{O} 7$ & $1.748(7)$ & $\mathrm{N} 2-\mathrm{H} 22$ & $0.9526(1)$ \\
\hline $\mathrm{A} 12-\mathrm{O} 10^{\mathrm{v}}$ & $1.780(7)$ & $\mathrm{N} 2-\mathrm{H} 23$ & $0.9526(1)$ \\
\hline
\end{tabular}




\begin{tabular}{|c|c|c|c|}
\hline $\mathrm{O} 1-\mathrm{P} 1$ & $1.493(6)$ & $\mathrm{N} 2-\mathrm{H} 24$ & $0.9526(1)$ \\
\hline $\mathrm{O} 1-\mathrm{H} 12^{\mathrm{vii}}$ & $1.88(2)$ & $\mathrm{N} 3-\mathrm{H} 31$ & $0.9526(1)$ \\
\hline $\mathrm{O} 1-\mathrm{H} 33^{\mathrm{vi}}$ & $1.897(15)$ & N3-H32 & $0.9526(1)$ \\
\hline $\mathrm{O} 2-\mathrm{P} 1$ & $1.550(7)$ & N3-H33 & $0.9526(1)$ \\
\hline $\mathrm{O} 2-\mathrm{A} 11^{\mathrm{vi}}$ & $1.732(7)$ & $\mathrm{N} 3-\mathrm{H} 34$ & $0.9526(1)$ \\
\hline $\mathrm{O} 1-\mathrm{P} 1-\mathrm{O} 2$ & $112.1(4)$ & $\mathrm{O}^{\mathrm{vi}}-\mathrm{A} 12-\mathrm{O} 10^{\mathrm{v}}$ & $109.6(3)$ \\
\hline $\mathrm{O} 1-\mathrm{P} 1-\mathrm{O} 3$ & $111.3(4)$ & $\mathrm{O} 7-\mathrm{A} 12-\mathrm{O} 10^{\mathrm{v}}$ & 108.1 \\
\hline $\mathrm{O} 1-\mathrm{P} 1-\mathrm{O} 4^{\mathrm{i}}$ & $114.6(4)$ & $\mathrm{P} 1-\mathrm{O} 2-\mathrm{A} 11^{\mathrm{vi}}$ & $147.3(5)$ \\
\hline $\mathrm{O} 2-\mathrm{P} 1-\mathrm{O} 3$ & $106.1(4)$ & $\mathrm{P} 1-\mathrm{O} 3-\mathrm{A} 11$ & $128.9(4)$ \\
\hline $\mathrm{O} 2-\mathrm{P} 1-\mathrm{O} 4^{\mathrm{i}}$ & $106.9(4)$ & $\mathrm{P} 11^{\mathrm{iv}}-\mathrm{O} 4-\mathrm{A} 12$ & $140.1(4)$ \\
\hline $\mathrm{O} 3-\mathrm{P} 1-\mathrm{O} 4^{\mathrm{i}}$ & $105.4(4)$ & $\mathrm{P} 2-\mathrm{O} 6-\mathrm{A} 12^{\mathrm{iii}}$ & $161.9(5)$ \\
\hline $\mathrm{O} 5-\mathrm{P} 2-\mathrm{O} 6$ & $110.3(4)$ & $\mathrm{P} 2-\mathrm{O} 7-\mathrm{A} 12$ & $135.6(5)$ \\
\hline $\mathrm{O} 5-\mathrm{P} 2-\mathrm{O} 7$ & $113.1(4)$ & $\mathrm{P} 2-\mathrm{O} 8-\mathrm{A} 11$ & $150.4(4)$ \\
\hline $\mathrm{O} 5-\mathrm{P} 2-\mathrm{O} 8$ & $108.9(4)$ & $\mathrm{P} 3-\mathrm{O} 10-\mathrm{A} 12^{\mathrm{ii}}$ & $139.0(5)$ \\
\hline $\mathrm{O} 6-\mathrm{P} 2-\mathrm{O} 7$ & $109.2(4)$ & $\mathrm{P} 3-\mathrm{O} 12-\mathrm{A} 11$ & $136.7(5)$ \\
\hline $\mathrm{O} 6-\mathrm{P} 2-\mathrm{O} 8$ & $107.8(4)$ & H11-N1-H12 & $109.4713(9)$ \\
\hline $\mathrm{O} 7-\mathrm{P} 2-\mathrm{O} 8$ & $107.4(4)$ & $\mathrm{H} 11-\mathrm{N} 1-\mathrm{H} 13$ & $109.4719(6)$ \\
\hline $\mathrm{O} 9-\mathrm{P} 3-\mathrm{O} 10$ & $111.1(4)$ & H11-N1-H14 & 109.4706 \\
\hline $\mathrm{O} 9-\mathrm{P} 3-\mathrm{O} 11^{\mathrm{i}}$ & $111.3(4)$ & $\mathrm{H} 12-\mathrm{N} 1-\mathrm{H} 13$ & $109.4715(1)$ \\
\hline $\mathrm{O} 9-\mathrm{P} 3-\mathrm{O} 12$ & $111.7(4)$ & $\mathrm{H} 12-\mathrm{N} 1-\mathrm{H} 14$ & 109.4704 \\
\hline $\mathrm{O} 10-\mathrm{P} 3-\mathrm{O} 11^{\mathrm{i}}$ & $110.0(4)$ & $\mathrm{H} 13-\mathrm{N} 1-\mathrm{H} 14$ & $109.4715(5)$ \\
\hline $\mathrm{O} 10-\mathrm{P} 3-\mathrm{O} 12$ & $103.2(3)$ & $\mathrm{H} 21-\mathrm{N} 2-\mathrm{H} 22$ & $109.4716(7)$ \\
\hline 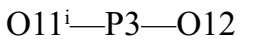 & $109.3(4)$ & $\mathrm{H} 21-\mathrm{N} 2-\mathrm{H} 23$ & $109.4710(4)$ \\
\hline $\mathrm{O} 22^{\mathrm{iii}}-\mathrm{A} 11-\mathrm{O} 3$ & $113.8(4)$ & $\mathrm{H} 21-\mathrm{N} 2-\mathrm{H} 24$ & $109.4716(4)$ \\
\hline $\mathrm{O} 2{ }^{\mathrm{iii}}-\mathrm{A} 11-\mathrm{O} 8$ & $105.8(4)$ & $\mathrm{H} 22-\mathrm{N} 2-\mathrm{H} 23$ & 109.4707 \\
\hline $\mathrm{O} 2^{\mathrm{iii}-\mathrm{A} 11-\mathrm{O} 12}$ & $108.6(4)$ & $\mathrm{H} 22-\mathrm{N} 2-\mathrm{H} 24$ & $109.4717(8)$ \\
\hline $\mathrm{O} 3-\mathrm{A} 11-\mathrm{O} 8$ & $104.1(3)$ & $\mathrm{H} 23-\mathrm{N} 2-\mathrm{H} 24$ & $109.4706(7)$ \\
\hline $\mathrm{O} 3-\mathrm{A} 11-\mathrm{O} 12$ & $107.6(4)$ & $\mathrm{H} 31-\mathrm{N} 3-\mathrm{H} 32$ & 109.4709 \\
\hline $\mathrm{O} 8-\mathrm{A} 11-\mathrm{O} 12$ & $117.2(4)$ & $\mathrm{H} 31-\mathrm{N} 3-\mathrm{H} 33$ & $109.4710(5)$ \\
\hline $\mathrm{O} 4-\mathrm{A} 12-\mathrm{O}^{\mathrm{vi}}$ & $108.1(3)$ & $\mathrm{H} 31-\mathrm{N} 3-\mathrm{H} 34$ & 109.4709 (1) \\
\hline $\mathrm{O} 4-\mathrm{A} 12-\mathrm{O} 7$ & $109.8(3)$ & $\mathrm{H} 32-\mathrm{N} 3-\mathrm{H} 33$ & 109.4717 \\
\hline $\mathrm{O} 4-\mathrm{A} 12-\mathrm{O} 10^{\mathrm{v}}$ & $108.5(4)$ & $\mathrm{H} 32-\mathrm{N} 3-\mathrm{H} 34$ & 109.472 \\
\hline $\mathrm{O}^{\mathrm{vi}}-\mathrm{A} 12-\mathrm{O} 7$ & $112.6(4)$ & $\mathrm{H} 33-\mathrm{N} 3-\mathrm{H} 34$ & 109.4709 \\
\hline
\end{tabular}

Symmetry codes: (i) $x, y, z-1$; (ii) $-x+1 / 2, y+1 / 2, z-1 / 2$; (iii) $x+1 / 2,-y+1 / 2, z$; (iv) $x, y, z+1$; (v) $-x+1 / 2, y-1 / 2, z+1 / 2$; (vi) $x-1 / 2,-y+1 / 2, z$; (vii) $x+1 / 2$, $-y+1 / 2, z-1$; (viii) $x-1, y, z ;$ (ix) $-x+1,-y+1, z+1 / 2 ;$ (x) $-x,-y+1, z-1 / 2$.

Hydrogen-bond geometry $\left(\AA,{ }^{\circ}\right)$

\begin{tabular}{lllll}
\hline$D-\mathrm{H} \cdots A$ & $D-\mathrm{H}$ & $\mathrm{H} \cdots A$ & $D \cdots A$ & $D-\mathrm{H} \cdots A$ \\
\hline $\mathrm{N} 1-\mathrm{H} 11 \cdots \mathrm{O}^{\text {iv }}$ & $0.95(4)$ & $2.39(4)$ & $3.250(10)$ & $151(3)$ \\
$\mathrm{N} 1-\mathrm{H} 11 \cdots \mathrm{O} 11$ & $0.95(4)$ & $2.35(5)$ & $3.163(8)$ & $143(3)$ \\
$\mathrm{N} 1-\mathrm{H} 12 \cdots \mathrm{O} 1^{\mathrm{xi}}$ & $0.95(4)$ & $1.88(4)$ & $2.791(10)$ & $159(3)$ \\
$\mathrm{N} 1-\mathrm{H} 13 \cdots \mathrm{O} 5$ & $0.95(4)$ & $2.14(4)$ & $2.934(10)$ & $141(3)$ \\
$\mathrm{N} 1-\mathrm{H} 14 \cdots 9^{\text {xii }}$ & $0.95(4)$ & $1.83(4)$ & $2.776(9)$ & $173(3)$ \\
$\mathrm{N} 2-\mathrm{H} 21 \cdots 5^{\text {xiii }}$ & $0.95(4)$ & $1.96(4)$ & $2.896(10)$ & $170(4)$ \\
$\mathrm{N} 2-\mathrm{H} 22 \cdots 8^{i i i}$ & $0.95(4)$ & $2.31(3)$ & $3.216(10)$ & $158(4)$ \\
$\mathrm{N} 2-\mathrm{H} 23 \cdots 9^{\text {xiii }}$ & $0.95(4)$ & $1.89(5)$ & $2.738(9)$ & $148(4)$
\end{tabular}


supporting information

$\begin{array}{lllll}\mathrm{N} 2-\mathrm{H} 24 \cdots \mathrm{O} 11^{\text {xiv }} & 0.96(4) & 1.86(4) & 2.818(9) & 174(5) \\ \mathrm{N} 3-\mathrm{H} 31 \cdots 5^{\text {xiv }} & 0.96(4) & 1.97(4) & 2.821(9) & 147(3) \\ \mathrm{N} 3-\mathrm{H} 32 \cdots \mathrm{O} 11^{\text {xiv }} & 0.952(15) & 1.85(2) & 2.728(8) & 153(4) \\ \mathrm{N} 3-\mathrm{H} 33 \cdots \mathrm{O} 1^{\mathrm{iii}} & 0.95(3) & 1.90(3) & 2.823(9) & 164(4) \\ \mathrm{N} 3-\mathrm{H} 34 \cdots \mathrm{O} 12 & 0.96(3) & 2.37(4) & 2.925(8) & 117(4)\end{array}$

Symmetry codes: (iii) $x+1 / 2,-y+1 / 2, z$; (iv) $x, y, z+1$; (xi) $x-1 / 2,-y+1 / 2, z+1$; (xii) $-x,-y+1, z+1 / 2$; (xiii) $x+1, y, z$; (xiv) $-x+1,-y+1, z-1 / 2$. 